\title{
Demographic Characteristics, Nicotine Dependence, and Motivation to Quit as Possible Determinants of Smoking Behaviors and Acceptability of Shocking Warnings in Italy
}

\author{
Alice Mannocci, ${ }^{1}$ Vittoria Colamesta, ${ }^{1}$ Vittoria Conti, ${ }^{2}$ Maria Sofia Cattaruzza, ${ }^{1}$ \\ Gregorino Paone, ${ }^{3}$ Maria Cafolla, ${ }^{1}$ Rosella Saulle, ${ }^{1}$ Vincenzo Bulzomì, ${ }^{4}$ Daniele Antici, ${ }^{1}$ \\ Pasquale Cuccurullo, ${ }^{5}$ Antonio Boccia, ${ }^{1}$ Giuseppe La Torre, ${ }^{1,6}$ and Claudio Terzano ${ }^{2}$ \\ ${ }^{1}$ Department Public Health and Infection Disease, Sapienza University of Rome, Piazzale Aldo Moro 5, 00185, Rome, Italy \\ ${ }^{2}$ Respiratory Diseases Unit and ALS Respiratory and Critical Care Unit, Policlinico Umberto I-Sapienza University of Rome, \\ 00185 Rome, Italy \\ ${ }^{3}$ Department of Cardiovascular, Respiratory, Nephrologic and Geriatric Sciences, San Camillo-Forlanini Hospital, \\ Sapienza University of Rome, 00149 Rome, Italy \\ ${ }^{4}$ Gynaecology Obstetric Department, Casilino Hospital, 00169 Rome, Italy \\ ${ }^{5}$ Clinic Center, 80126 Naples, Italy \\ ${ }^{6}$ Fondazione Eleonora Lorillard Spencer Cenci, Sapienza University of Rome, 00185 Rome, Italy
}

Correspondence should be addressed to Alice Mannocci; alice.mannocci@uniromal.it

Received 11 February 2014; Accepted 10 April 2014; Published 12 May 2014

Academic Editor: Maria Caterina Grassi

Copyright (C) 2014 Alice Mannocci et al. This is an open access article distributed under the Creative Commons Attribution License, which permits unrestricted use, distribution, and reproduction in any medium, provided the original work is properly cited.

Introduction. This paper presents the final results of a cross-sectional study started in 2010. It compares the perceived efficacy of different types of tobacco health warning (texts versus shocking pictures) to quit or reduce tobacco use. Methods. The study conducted between 2010 and 2012 in Italy enrolled adults smokers. Administering a questionnaire demographic data, smokers behaviors were collected. Showing text and graphic warnings (the corpse of a smoker, diseased lungs, etc.) the most perceived efficacy to reduce tobacco consumption or to encourage was quit. Results. 666 subjects were interviewed; $6 \%$ of responders referred that they stopped smoking at least one month due to the textual warnings. The $81 \%$ of the smokers perceived that the warnings with shocking pictures are more effective in reducing/quitting tobacco consumption than text-only warnings. The younger group ( $<45$ years), who are more motivated to quit (Mondor's score $\geq 12$ ), and females showed a higher effectiveness of shocking warnings to reduce tobacco consumption of, $76 \%, 78 \%$, and $43 \%$, respectively with $P<0.05$. Conclusions. This study suggests that pictorial warnings on cigarette packages are more likely to be noticed and rated as effective by Italian smokers. Female and younger smokers appear to be more involved by shock images. The jarring warnings also appear to be supporting those who want to quit smoking. This type of supportive information in Italy may become increasingly important for helping smokers to change their behavior.

\section{Introduction}

Worldwide tobacco use continues to cause more deaths, nearly 6 million, and costs hundreds of billions of dollars of economic damage each year. If current trends continue, it will cause more than 8 million deaths annually by 2030 [1].

This high burden of tobacco is related to the causal association between smoking and a wide range of diseases.
In fact, 10 types of cancer and 18 other diseases (including abdominal aortic aneurysm, acute myeloid leukemia, cataract, cervical cancer, kidney cancer, pancreatic cancer, pneumonia, periodontitis, and stomach cancer) are identified as smoking-related diseases $[2,3]$.

There has been a progressive decrease of the incidence of Italian smokers; in 50 years, the prevalence was estimated at $35.4 \%$; recently, in 2012 , the prevalence has fallen to $20.8 \%$. 
(24.6\% men and $17.2 \%$ women) [4]. In particular, over the past 5 years, the prevalence of smoking appears to remain fairly constant and fluctuates between $21 \%$ and $23 \%$. This could be also due to the fact that the policies on smoking in Italy have not been very incisive as in the past. No coincidence that the last major legislation on the fight against smoking dates back to 2003 with the ban on smoking in public places. Also regarding the introduction of text warnings, which was in 1991 in Italy, this may not be the most effective, as these now may no longer be noticed as at the beginning. In the report, DOXA 2012, also, reports that the choice to consume a particular brand of cigarettes can also be influenced by the look of the package (colors, lettering, and graphics) with $1.5 \%$ a lot, $10.4 \%$ sufficiently, $32.8 \%$ not a lot, and $55 \%$ in no way [4]. Today the Italian population could be addicted to a type of warnings, so as not to feel the contents of the messages. This could lead to a difficulty in further reduction of the incidence of number of smokers. Health warnings on smoked tobacco products represent a significant area of tobacco control policy. Health warnings on tobacco packages are an important medium for communicating the tobaccorelated risks to consumers.

The impact of health warning varies as "the pictorial warnings are more likely to be noticed, are associated with greater levels of engagement and emotional arousal, and may "wear out" more slowly than text-only warnings" [5]; "health warning labels had a greater cognitive and behavioral impact than either the abstract imagery or the text-only" [6]; the warnings increased the motivation to quit and reduce the number of cigarettes [7].

In Canada, graphic warnings have significant effect on smoking prevalence and quit attempts, decreasing the odds of being a smoker and increasing the odds of making a quit attempt [8].

In USA, the Food and Drug Administration (FDA) proposed 36 graphic warning labels and planned to select 9 to use. In young adults, the proposed labels had greater effects than text-only warning on fear-related reactions, smoking motivation, and discouragement with greater effect on nonsmokers than smokers. Images with babies or children or suffering or dead people or diseased body parts had the greatest effect on discouragement from smoking [9].

Also health warning could have a protective effect on recent quitters ( $<1$ year) to stay a quitter [10].

In Europe, a recent study provides evaluation of the effectiveness of the text health warnings among daily cigarette smokers in four member states. The impact varies across the countries; in particular, it is higher where there is more comprehensive tobacco control programs among smokers with lowest socioeconomic status, who had made a quit attempt in the past year and smokers who smoked fewer cigarettes per day. The highest scores of Labels Impact Index (LII), used to quantify the effect, were found in France; while lower ones were in UK, the lowest scores were observed in Germany and The Netherlands [1].

This study represents the conclusion of a pilot survey published in 2012 [11]. In the previous paper, 243 current smokers were involved.
The main aim of the present study was to propose the final results expanding the sample size $(N=666)$ in order to verify the perception of the warning on cigarette packages in Italy in quitting smoking or in reducing the number of cigarettes smoked daily stratified by demographic characteristics, nicotine dependence, and motivation to quit. In addition, another objective of the study was to carry out a comparison of effectiveness between the text warnings, according to Italian law, compared to health warning graphics, according to some legislation in other countries.

In the present paper, the perceived efficacy to reduce tobacco consumption or to encourage quit was indicated using the following acronym: PERTC.

\section{Methods}

A cross-sectional study was conducted between June 2010 and September 2012 in three sites of Center and Southern Italy, Rome, Taranto, and Naples. The subjects enrolled were adult smokers (years $\geq 18$ ).

The individuals were invited to complete a selfquestionnaire in the waiting rooms of respiratory, orthopedic, or gynecological outpatient clinics, in the waiting rooms of a smoking cessation center, or during the hygiene lessons in the first year of the health professions students.

The STROBE statement was applied to present the results' study [12].

A multiple-choice questionnaire was developed to investigate the sociodemographic characteristics (age, gender) and smoke habits (number of cigarettes smoked daily, years of smoke) and how much actually the labels of the cigarettes packaging were appreciated and their perceived effectiveness for smoking cessation or reduction (see Table 1).

Addictional two different types of warnings were shown to the smokers during the interview (see Figures 1(a) and 1(b)): only text (current warning used in Italy, i.e., "Smoking kills") and pictorial "shocking" warnings (i.e., the corpse of a smoker, diseased lungs, throat cancer, and rotting teeth). After that, to quantify the effect of the warning, two questions were asked: "If your favorite cigarettes brand decides to change his look using these pictorial warnings on tobacco packaging, would you think of buy another cigarettes brand?" Yes/no; "If you could choose the types of warning labels on cigarette packs, which one do you feel as more effective in helping to stop smoking?" Graphic images/texts/a combination of both.

In addition, the Fagerström and Mondor questionnaires $[13,14]$ were administered to estimate the nicotine dependence and motivation to stop smoking. The nicotine dependence and motivation to stop smoking were dichotomized (high versus low score) using as cutoff point Fagerström's score over 4 and Mondor's score $\geq 12$, respectively.

2.1. Statistical Analysis. Statistical analysis was performed using SPSS for Windows (Statistical Package for the Social Sciences, Version 19; SPSS Inc., Chicago, IL, USA). Categorical data were shown as absolute frequencies and percentages. Continuous data were presented as means \pm standard 
TABle 1: Description of the sample.

\begin{tabular}{|c|c|c|c|c|}
\hline Variables & & $N$ & $(\%)$ & Missing* \\
\hline \multirow{2}{*}{ Gender } & Female & 346 & 52.5 & \multirow{2}{*}{7} \\
\hline & Male & 313 & 47.5 & \\
\hline \multirow{2}{*}{ Age } & $<45$ years & 332 & 49.9 & \multirow[t]{2}{*}{1} \\
\hline & $\geq 45$ years & 333 & 50.1 & \\
\hline \multirow{3}{*}{ Number of daily cigarettes } & $0-9$ & 184 & 27.8 & \multirow{3}{*}{4} \\
\hline & $10-25$ & 390 & 58.9 & \\
\hline & $>25$ & 88 & 13.3 & \\
\hline \multirow{4}{*}{ Years of smoking } & $<6$ years & 97 & 14.6 & \multirow{4}{*}{2} \\
\hline & $6-15$ years & 170 & 25.6 & \\
\hline & $16-25$ years & 120 & 18.1 & \\
\hline & $>25$ years & 277 & 41.7 & \\
\hline \multirow{2}{*}{ Fagerström score (nicotine dependence) } & High & 413 & 68.5 & \multirow{2}{*}{63} \\
\hline & Low & 190 & 31.5 & \\
\hline \multirow{2}{*}{ Mondor's score (motivation to quit) } & High & 293 & 48.6 & \multirow[t]{2}{*}{63} \\
\hline & Low & 310 & 51.4 & \\
\hline \multirow{2}{*}{ Are you aware of the damage caused by smoking? } & Yes & 643 & 98 & \multirow[t]{2}{*}{10} \\
\hline & No & 13 & 2 & \\
\hline \multirow{8}{*}{$\begin{array}{l}\text { What is the consequence that in the immediate worries you? } \\
\text { (Multiple answer question) }\end{array}$} & Wrinkles & 104 & 15.6 & \multirow{8}{*}{1} \\
\hline & Skin spots & 104 & 15.6 & \\
\hline & Breathlessness & 336 & 50.5 & \\
\hline & Halitosis or bad breath & 135 & 20.3 & \\
\hline & Yellow teeth & 133 & 20 & \\
\hline & Yellow fingernails & 10 & 2.6 & \\
\hline & Hair loss & 13 & 3.1 & \\
\hline & Bad smelling clothes & 92 & 13.8 & \\
\hline \multirow{2}{*}{ Have you ever stopped smoking due to the warnings? } & Yes & 41 & 6.2 & \multirow[t]{2}{*}{9} \\
\hline & No & 616 & 93.8 & \\
\hline $\begin{array}{l}\text { Are you or have you been influenced by the health warnings on } \\
\text { cigarettes packages (in relation to the daily number of cigarettes } \\
\text { smoked)? }\end{array}$ & $\begin{array}{l}\text { Yes } \\
\text { No }\end{array}$ & $\begin{array}{c}80 \\
560\end{array}$ & $\begin{array}{l}12.5 \\
87.5\end{array}$ & 26 \\
\hline \multirow{2}{*}{$\begin{array}{l}\text { Have you changed your smoking habits due to the warnings (e.g., do } \\
\text { not smoke after coffee)? }\end{array}$} & Yes & 52 & 8.2 & \multirow{2}{*}{28} \\
\hline & No & 586 & 91.8 & \\
\hline \multirow{2}{*}{$\begin{array}{l}\text { If yes. Have you returned to your previous smoking habits after a } \\
\text { short time? }\end{array}$} & Yes & 25 & 69.4 & \multirow{2}{*}{14} \\
\hline & No & 11 & 30.6 & \\
\hline \multirow[t]{2}{*}{ Having read the smoking warnings on packages. Do you inhale it? } & Yes & 596 & 90.3 & 6 \\
\hline & No & 64 & 9.7 & \\
\hline & A lot & 170 & 25.9 & \\
\hline Do you consider it important to report the health warnings about & Enough & 176 & 26.8 & 9 \\
\hline & Poor & 186 & 28.3 & \\
\hline & No & 125 & 19.0 & \\
\hline Have the messages communicated that smoking ruins your health? & Yes & 563 & 87.6 & 23 \\
\hline 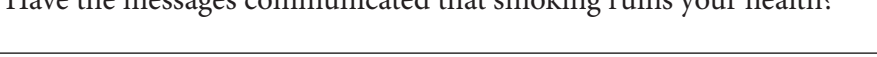 & No & 80 & 12.4 & \\
\hline Have the messages communicated to you that smoking causes damage & Yes & 534 & $\begin{array}{l}85.3 \\
147\end{array}$ & 40 \\
\hline to those around you, such as your children or family members? & No & 92 & 14.7 & 70 \\
\hline
\end{tabular}


TABle 1: Continued.

\begin{tabular}{|c|c|c|c|c|}
\hline Variables & & $N$ & $(\%)$ & Missing ${ }^{*}$ \\
\hline \multirow{4}{*}{$\begin{array}{l}\text { Have the health warnings increased the curiosity or the desire to be } \\
\text { better informed or to be helped to give up smoking? }\end{array}$} & A lot & 50 & 7.6 & \multirow{4}{*}{9} \\
\hline & Enough & 188 & 28.6 & \\
\hline & Poor & 258 & 39.3 & \\
\hline & No & 161 & 24.5 & \\
\hline \multirow{2}{*}{$\begin{array}{l}\text { Do you think that the light, blue, gold, and mild cigarettes are less } \\
\text { hazardous than regular cigarettes? }\end{array}$} & Yes & 140 & 24.3 & \multirow[t]{2}{*}{91} \\
\hline & No & 435 & 75.7 & \\
\hline \multirow{3}{*}{$\begin{array}{l}\text { If shocking images were used on cigarette boxes, would they have } \\
\text { greater effect than simple warning text currently used? }\end{array}$} & Yes & 395 & 62.0 & \multirow{3}{*}{29} \\
\hline & No & 95 & 14.9 & \\
\hline & Do not know & 147 & 23.1 & \\
\hline \multirow{4}{*}{$\begin{array}{l}\text { If you could choose the types of warning labels on cigarette packs, } \\
\text { which one do you feel as more effective in helping to stop smoking? }\end{array}$} & Textual health warning & 92 & 14.2 & \multirow{4}{*}{16} \\
\hline & $\begin{array}{l}\text { Graphic health warnings } \\
\text { with shocking images }\end{array}$ & 152 & 23.4 & \\
\hline & $\begin{array}{l}\text { Both shocking images with } \\
\text { text }\end{array}$ & 303 & 46.6 & \\
\hline & Do not know & 103 & 15.8 & \\
\hline \multirow{3}{*}{$\begin{array}{l}\text { If your favorite cigarettes brand decided to change the look of its } \\
\text { cigarette boxes with shocking images on smoking health damages, } \\
\text { would you think of changing it? }\end{array}$} & Yes & 154 & 23.7 & \multirow{3}{*}{16} \\
\hline & No & 250 & 38.5 & \\
\hline & Do not know & 246 & 37.8 & \\
\hline
\end{tabular}

*Missing values or answer "I do not know."

${ }^{\circ}$ The sample size in this case is 36.

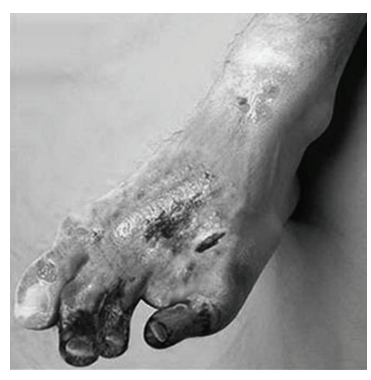

FIGURE 1: (a) Examples of pictorial health warnings.

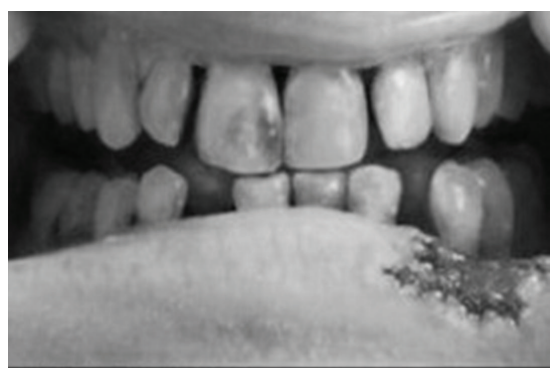

(a)

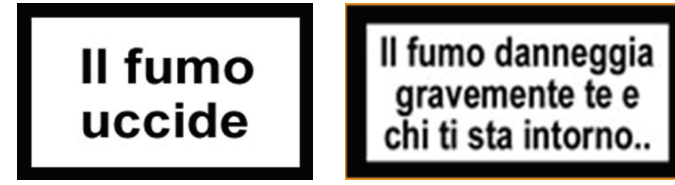

(b) deviation (SD) or medians (interquartile ranges, IR), as appropriate.

The nicotine dependence and motivation to stop smoking and the associations by gender and age groups were compared by the chi-square test or the Fisher's exact test whenever the sample sizes were rather small.

The following two logistic multivariate regression models were computed using as outcome two questions concerning the impact of the graphic warnings:

(i) if shocking images were used on cigarette boxes, would they have greater effect than simple warning text currently used? Yes/no;

(ii) if your favorite cigarettes brand decides to change his look using pictorial warnings on tobacco packaging, would you think of buying another cigarette brand? Yes/no.
The independent factors included in the models were followed dummies variables: gender, age groups ( $<45$ years), nicotine dependence (high/low), and motivation to stop smoking (high/low). The ORs adjusted for the covariates with CI95\% were indicated.

The Hosmer and Lemeshow test was applied to estimate the goodness of fit for each model.

The statistical significance was set at $P<0.05$.

\section{Results}

A total of 666 smokers entered the study; $47.5 \%(N=313)$ of the responders was male; $49.9 \%(N=332)$ had $<45$ years old (mean age $=45$ years; $\mathrm{SD}=17.5$ years).

The mean duration of tobacco use was 24 years $(\mathrm{SD}=$ 16.6 years) (data are not reported in table); $58.9 \%$ of the 
TABLE 2: Description and comparison by gender and age groups. For dichotomous variables (yes/no), "Yes" percentage was reported only.

\begin{tabular}{|c|c|c|c|c|c|c|c|}
\hline Variables & & Male $N(\%)$ & Female $N(\%)$ & $P^{\wedge}$ & $\begin{array}{c}<45 \\
\text { years } \\
N(\%)\end{array}$ & $\begin{array}{c}\geq 45 \\
\text { years } \\
N(\%)\end{array}$ & $P^{\wedge}$ \\
\hline Are you aware of the damage caused by smoking? & Yes & $309(99)$ & $329(97)$ & 0.070 & $323(98)$ & $320(99)$ & 0.420 \\
\hline \multirow{8}{*}{$\begin{array}{l}\text { What is/are the consequence/s that in the } \\
\text { immediate worries you? (Multiple-answers) }\end{array}$} & Wrinkles & $27(9)$ & $77(22)$ & $<0.001$ & $78(24)$ & $26(8)$ & $<0.001$ \\
\hline & Skin spots & $42(40)$ & $62(60)$ & 0.110 & $67(20)$ & 37 (11) & 0.001 \\
\hline & Breathlessness & $176(56)$ & $154(45)$ & 0.003 & $162(49)$ & $173(52)$ & 0.393 \\
\hline & $\begin{array}{l}\text { Halitosis or bad } \\
\text { breath }\end{array}$ & $58(19)$ & $76(22)$ & 0.266 & $94(28)$ & $40(12)$ & $<0.001$ \\
\hline & Yellow teeth & $56(18)$ & $77(22)$ & 0.158 & $97(29)$ & $36(11)$ & $<0.001$ \\
\hline & $\begin{array}{l}\text { Yellow } \\
\text { fingernails }\end{array}$ & $4(2)$ & $7(3)$ & 0.445 & $11(7)$ & $0(0)$ & $<0.001^{*}$ \\
\hline & Hair loss & $3(2)$ & $10(5)$ & 0.071 & $10(6)$ & $3(1)$ & 0.004 \\
\hline & $\begin{array}{l}\text { Bad smelling } \\
\text { clothes }\end{array}$ & $33(11)$ & $58(17)$ & 0.020 & $50(15)$ & $41(12)$ & 0.310 \\
\hline $\begin{array}{l}\text { Have you ever stopped smoking due to the } \\
\text { warnings? (Decision to quit) }\end{array}$ & Yes & $25(8)$ & $14(4)$ & 0.034 & $15(5)$ & $26(8)$ & 0.067 \\
\hline $\begin{array}{l}\text { Are you or have you been influenced by the } \\
\text { health warnings on cigarettes packages } \\
\text { (in relation to the daily number of cigarettes } \\
\text { smoked)? } \\
\text { (Foregoing of cigarettes) }\end{array}$ & Yes & $28(9)$ & $51(15)$ & 0.020 & $37(11)$ & $43(14)$ & 0.370 \\
\hline $\begin{array}{l}\text { Have you changed your smoking habits due to } \\
\text { the warnings (e.g., do not smoke after coffee)? } \\
\text { (Forgoing of cigarettes) }\end{array}$ & Yes & $23(7)$ & $29(9)$ & 0.583 & $29(9)$ & $23(7)$ & 0.497 \\
\hline $\begin{array}{l}\text { If yes. Have you returned to yours previous } \\
\text { smoking habits after a short time? }\end{array}$ & Yes & $12(75)$ & $13(65)$ & $0.718^{*}$ & $13(77)$ & $12(63)$ & 0.387 \\
\hline $\begin{array}{l}\text { Having read the smoking warnings on } \\
\text { packages, do you inhale it? }\end{array}$ & Yes & $294(94)$ & 297 (87) & 0.002 & $306(93)$ & $289(88)$ & 0.034 \\
\hline \multirow{4}{*}{$\begin{array}{l}\text { Do you consider it important to report the } \\
\text { health warnings about tobacco consumption on } \\
\text { cigarette packs? }\end{array}$} & A lot & $83(27)$ & $84(25)$ & \multirow{4}{*}{0.468} & $98(30)$ & $71(22)$ & \multirow{4}{*}{0.048} \\
\hline & Enough & $82(27)$ & $92(21)$ & & $92(28)$ & $84(26)$ & \\
\hline & Poor & $94(30)$ & $92(27)$ & & $82(25)$ & $104(32)$ & \\
\hline & No & $52(17)$ & $72(21)$ & & $58(18)$ & $67(21)$ & \\
\hline $\begin{array}{l}\text { Have the messages communicated that } \\
\text { smoking ruins your health? (Thoughts of harm) }\end{array}$ & Yes & $268(88)$ & $290(87)$ & 0.929 & $293(90)$ & $270(85)$ & 0.071 \\
\hline $\begin{array}{l}\text { Have the messages communicated to you that } \\
\text { smoking causes damages to those around } \\
\text { you, such as your children or family } \\
\text { members? (Thoughts of harm) }\end{array}$ & Yes & $252(85)$ & $280(86)$ & 0.641 & 287 (89) & $246(82)$ & 0.009 \\
\hline \multirow{4}{*}{$\begin{array}{l}\text { Have the health warnings increased the } \\
\text { curiosity or the desire to be better informed } \\
\text { or to be helped to give up smoking? } \\
\text { (Warning salience) }\end{array}$} & A lot & $27(9)$ & $21(6)$ & \multirow{4}{*}{0.153} & $21(6)$ & $29(9)$ & \multirow{4}{*}{$<0.001$} \\
\hline & Enough & $83(27)$ & $104(31)$ & & $120(36)$ & $68(21)$ & \\
\hline & Poor & $132(42)$ & $124(36)$ & & $116(35)$ & $142(44)$ & \\
\hline & No & $69(22)$ & $92(27)$ & & $74(22)$ & $87(27)$ & \\
\hline $\begin{array}{l}\text { Do you think that the light, blue, gold, and mild } \\
\text { cigarettes are less hazardous than regular } \\
\text { cigarettes? }\end{array}$ & Yes & $67(25)$ & $73(24)$ & 0.762 & $58(20)$ & $82(29)$ & 0.022 \\
\hline $\begin{array}{l}\text { If shocking images were used on cigarette boxes, } \\
\text { would they have greater effect than simple } \\
\text { warning text currently used? }\end{array}$ & Yes & $194(83)$ & $197(78)$ & 0.189 & 215 (85) & $180(76)$ & 0.019 \\
\hline $\begin{array}{l}\text { If your favorite cigarettes brand decide to } \\
\text { change the look of its cigarette boxes with } \\
\text { shocking images on smoking health damages, } \\
\text { would you think of changing it? }\end{array}$ & Yes & $60(32)$ & $92(43)$ & 0.025 & $81(40)$ & $73(36)$ & 0.390 \\
\hline
\end{tabular}


TABLE 2: Continued.

\begin{tabular}{|c|c|c|c|c|c|c|c|}
\hline Variables & & Male N (\%) & Female $N(\%)$ & $P^{\wedge}$ & $\begin{array}{c}<45 \\
\text { years } \\
N(\%) \\
\end{array}$ & $\begin{array}{c}\geq 45 \\
\text { years } \\
N(\%) \\
\end{array}$ & $P^{\wedge}$ \\
\hline \multirow{3}{*}{$\begin{array}{l}\text { If you could choose the types of warning labels } \\
\text { on cigarette packs, which one do you feel as more } \\
\text { effective in helping to stop smoking? }\end{array}$} & $\begin{array}{l}\text { Textual health } \\
\text { warning }\end{array}$ & $45(17)$ & $46(17)$ & \multirow{3}{*}{0.985} & $43(15)$ & 49 (19) & \multirow{3}{*}{0.480} \\
\hline & $\begin{array}{l}\text { Graphic health } \\
\text { warnings with } \\
\text { shocking images }\end{array}$ & $72(27)$ & $77(28)$ & & $81(28)$ & $71(27)$ & \\
\hline & $\begin{array}{l}\text { Both shocking } \\
\text { images with text }\end{array}$ & $148(56)$ & $155(56)$ & & $163(57)$ & $140(54)$ & \\
\hline
\end{tabular}

${ }^{\wedge} P$ value chi-square test; ${ }^{*} P$ value Fisher's exact test; ${ }^{\circ}$ the sample size in this case is 36 ; bold: $P<0.05$.

sample smoked 10-25 cigarettes per day, $27.8 \%$ less than 10 , and $13.3 \%$ more than 25 .

$68.5 \%$ of smokers had medium high nicotine dependence (Fagerström's score $>4$ ) and $51.4 \%$ a low motivation to quit (Mondor's score $<12$ ); it has not been possible to calculate the scores in $9.5 \%$ of the cases due to missing values.

Table 1 shows the answers obtained. Almost all of the subjects $(98 \%)$ were aware of health consequences. Concerning the short-term effects of tobacco consumption, the major worries referred were breathlessness $(50.5 \%)$, yellow teeth (20\%), halitosis, or bad breath (20.3\%).

A very low percentage of smokers referred that they stopped smoking at least one month due to the warnings $(6.2 \%)$, so also there is a soft influence on the smokers habits, in particular $12.5 \%$, that referred a reduction of the daily number of cigarettes smoked, and $8.2 \%$ do not smoke just waking up in the morning or after drinking a cup of coffee.

One fourth of the sample $(24.3 \%)$ did not know that individuals smoking light, mild, and blue cigarettes are likely to inhale the same amount of hazardous chemicals and remain at high risk for developing smoking-related cancers and other diseases.

$62 \%$ of the smokers declared that the warnings with shocking pictures have a more effective communication in order to reduce/quit tobacco consumption than text-only warnings, and the combinations of text and shocking images were the most preferred (46.6\%). In addition one smoker out of four $(23.7 \%)$ would have changed the brand of cigarettes if it decided to print shocking pictorial advertisements on smoking health damages.

Table 2 shows the comparison by gender and age groups. Women seemed to be more sensitive by the effects of smoking on the physical aspect, in particular, on wrinkles and smelly clothes $(22 \% P<0.001 ; 17 \% P=0.020)$; they seem to have been impressed by the current warnings reducing the daily consumption of tobacco (15\% of women versus $9 \%$ of men, $P=0.020$ ), and they would be inclined not to buy their favorite package if there are printed gruesome images on the health effects of smoking ( $43 \%$ female versus $32 \%$ male, $P=0.025)$.

The actual textual warning had a different effect on persuading to not inhale tobacco: $87 \%$ in women versus $94 \%$ in men $(P=0.002)$.
On the other hand, the males were more worried about the physical fitness with special reference to the breathlessness (56\% versus $45 \%, P=0.003$ ); they had stopped smoking for a short time thanks to the warnings ( $8 \%$ versus $4 \%, P=$ $0.034)$ even though they then restarted smoking again as before (75\%).

Young smokers ( $<45$ years) showed a significantly higher worry for those aspects related to both the appearance of the face and the physical form than the older ones: wrinkles, skin spots, halitosis, yellow teeth and nails, and hair loss.

Younger age group also showed a greater attention to warnings, curiosity and bad knowledge about tobacco, and the damage it caused (93\% versus $88 \%, P=0.034 ; 89 \%$ versus $82 \%, P=0.009 ; 42 \%$ versus $30 \%, P<0.001 ; 20 \%$ versus $29 \%, P=0.022)$ and they were also more sensitive to pictorial warnings ( $85 \%$ versus $76 \%, P=0.019$ ).

The comparison of the two different dependences on smoking and motivation to quit groups shows some significant differences (Table 3).

The group more motivated to stop smoking, in comparison with the one not motivated, is more informed (resp., $89 \%$ versus $82 \%, P=0.019)$ and considers the labels crucial to increase the awareness and the motivation to reduce/quit tobacco consumption $(P=0.021)$, and it was not by chance that this group considers the warnings with graphic text most appropriate to fight the habit of smoking $(P=0.003)$. The higher significant percentage of motivated smokers reported that the health warning increase the curiosity (42\% versus $31 \%, P=0.023)$. The consequences more referred in the high motivated groups are breathlessness, skin spots, and yellow fingernails.

In the group that shows a high nicotine dependence, there was bigger unawareness of the effects of smoking on health (78\% versus $69 \%, P=0.044$ ) and a less impressionability by shocking images ( $78 \%$ versus $87 \%, P=0.018$ ).

The multivariate logistics analysis confirmed significant higher effect the shocking warnings in younger and lower dependent smokers (see Table 4), respectively, OR $=0.59$ for older smokers (CI95\%: 0.36-0.97) and OR $=0.46$ for high nicotine dependence (CI95\%: 0.26-0.84). No significant difference was found concerning changing the favorite cigarette brand in case the company adopts the shock labeling. 
TABle 3: Description and comparison by motivation to quit and smoke dependence groups. For dichotomous variables (yes/no), "yes" percentage was reported only.

\begin{tabular}{|c|c|c|c|c|c|c|c|}
\hline Variables & & $\begin{array}{l}\text { Low } \\
\text { motivation } \\
N(\%)\end{array}$ & $\begin{array}{l}\text { High } \\
\text { motivation } \\
N(\%)\end{array}$ & $P^{\wedge}$ & $\begin{array}{c}\text { Low } \\
\text { dependence } \\
N(\%)\end{array}$ & $\begin{array}{c}\text { High } \\
\text { dependence } \\
N(\%)\end{array}$ & $P^{\wedge}$ \\
\hline $\begin{array}{l}\text { Are you aware of the damage caused by } \\
\text { smoking? }\end{array}$ & Yes & 299 (98) & $284(98)$ & 0.629 & $182(97)$ & $403(98)$ & $0.208^{*}$ \\
\hline \multirow{8}{*}{$\begin{array}{l}\text { What is/are the consequence/s that in the } \\
\text { immediate worries you? (Multiple answers) }\end{array}$} & Wrinkles & $46(15)$ & $55(19)$ & 0.196 & $29(15)$ & 70 (17) & 0.604 \\
\hline & Skin spots & $64(21)$ & $39(13)$ & 0.017 & $31(16)$ & $69(17)$ & 0.904 \\
\hline & Breathlessness & $141(46)$ & $161(55)$ & 0.020 & $92(48)$ & $212(51)$ & 0.507 \\
\hline & $\begin{array}{l}\text { Halitosis or } \\
\text { bad breath }\end{array}$ & $65(21)$ & $64(22)$ & 0.793 & $37(20)$ & $86(21)$ & 0.702 \\
\hline & Yellow teeth & $56(18)$ & $70(24)$ & 0.079 & $38(20)$ & $86(21)$ & 0.816 \\
\hline & $\begin{array}{l}\text { Yellow } \\
\text { fingernails }\end{array}$ & $9(5)$ & $2(1)$ & 0.024 & $5(4)$ & $5(2)$ & $0.302^{*}$ \\
\hline & Hair loss & $4(2)$ & $8(4)$ & 0.290 & $2(2)$ & $9(4)$ & $0.514^{*}$ \\
\hline & $\begin{array}{l}\text { Bad smelling } \\
\text { clothes }\end{array}$ & $51(17)$ & $38(13)$ & 0.228 & $21(11)$ & $60(15)$ & 0.245 \\
\hline $\begin{array}{l}\text { Have you ever stopped smoking due to the } \\
\text { warnings? (decision to quit) }\end{array}$ & Yes & $18(6)$ & $18(6)$ & 0.885 & $13(7)$ & $26(6)$ & 0.817 \\
\hline $\begin{array}{l}\text { Are you or have you been influenced by the } \\
\text { health warnings on cigarettes packages (in } \\
\text { relation to the daily number of cigarettes } \\
\text { smoked)? (Foregoing of cigarettes) }\end{array}$ & Yes & $31(10)$ & $43(15)$ & 0.090 & $28(15)$ & $44(11)$ & 0.175 \\
\hline $\begin{array}{l}\text { Have you changed your smoking habits due } \\
\text { to the warnings (e.g., do not smoking after } \\
\text { coffee)? (Foregoing of cigarettes) }\end{array}$ & Yes & $22(7)$ & $25(9)$ & 0.515 & $17(9)$ & $29(7)$ & 0.444 \\
\hline $\begin{array}{l}{ }^{\circ} \text { If yes. Have you returned to your previous } \\
\text { smoking habits after a short time? }\end{array}$ & Yes & $11(79)$ & $12(67)$ & $0.457^{*}$ & $9(56)$ & $14(82)$ & $0.141^{*}$ \\
\hline $\begin{array}{l}\text { Having read the smoking warnings on } \\
\text { packages, do you inhale it? }\end{array}$ & Yes & $280(91)$ & $265(90)$ & 0.943 & $162(85)$ & $386(94)$ & 0.001 \\
\hline \multirow{4}{*}{$\begin{array}{l}\text { Do you consider it important to report the } \\
\text { health warnings about tobacco consumption } \\
\text { on cigarette packs? }\end{array}$} & A lot & $63(21)$ & $90(31)$ & \multirow{4}{*}{0.021} & $52(27.5)$ & $97(24)$ & \multirow{4}{*}{0.087} \\
\hline & Enough & $95(31)$ & $68(23)$ & & $52(27.5)$ & $116(28)$ & \\
\hline & Poor & $89(29)$ & $83(28)$ & & $60(32)$ & $110(27)$ & \\
\hline & No & $60(19)$ & $52(18)$ & & $25(13)$ & $88(21)$ & \\
\hline $\begin{array}{l}\text { Have the messages communicated that } \\
\text { smoking ruins your health? (Thoughts of } \\
\text { harm) }\end{array}$ & Yes & $258(86)$ & $259(90)$ & 0.150 & $169(90)$ & $347(87)$ & 0.249 \\
\hline $\begin{array}{l}\text { Have the messages communicated to you that } \\
\text { smoking causes damage to those around } \\
\text { you, such as your children or family } \\
\text { members? (Thoughts of harm) }\end{array}$ & Yes & $245(82)$ & 247 (89) & 0.019 & $160(87)$ & $328(84)$ & 0.296 \\
\hline \multirow{4}{*}{$\begin{array}{l}\text { Have the health warnings increased the } \\
\text { curiosity or the desire to be better informed } \\
\text { or to be helped to give up smoking? } \\
\text { (Warning salience) }\end{array}$} & A lot & $18(6)$ & $24(8)$ & \multirow{4}{*}{0.023} & $17(9)$ & $27(7)$ & \multirow{4}{*}{0.070} \\
\hline & Enough & $78(25)$ & $100(34)$ & & $60(32)$ & $115(28)$ & \\
\hline & Poor & $125(41)$ & $111(38)$ & & $80(42)$ & $158(38)$ & \\
\hline & No & $86(28)$ & $58(20)$ & & $33(17)$ & $111(27)$ & \\
\hline $\begin{array}{l}\text { Do you think that the light, blue, } \\
\text { gold, and mild cigarettes are less hazardous } \\
\text { than regular cigarettes? }\end{array}$ & Yes & $72(26)$ & $57(22)$ & 0.305 & $52(31)$ & $79(22)$ & 0.044 \\
\hline $\begin{array}{l}\text { If shocking images were used on cigarette } \\
\text { boxes, would they have greater effect than } \\
\text { simple warning text currently used? }\end{array}$ & Yes & $178(78)$ & $183(84)$ & 0.114 & $124(87)$ & $236(78)$ & 0.018 \\
\hline $\begin{array}{l}\text { If your favorite cigarettes brand/company } \\
\text { decide to change the look of its cigarette } \\
\text { boxes with shocking images on smoking } \\
\text { health damage, would you think of changing } \\
\text { it? }\end{array}$ & Yes & $71(37)$ & $73(41)$ & 0.424 & $53(46)$ & $93(37)$ & 0.095 \\
\hline
\end{tabular}


TABle 3: Continued.

\begin{tabular}{|c|c|c|c|c|c|c|c|}
\hline Variables & & $\begin{array}{l}\text { Low } \\
\text { motivation } \\
N(\%)\end{array}$ & $\begin{array}{l}\text { High } \\
\text { motivation } \\
N(\%)\end{array}$ & $P^{\wedge}$ & $\begin{array}{c}\text { Low } \\
\text { dependence } \\
N(\%)\end{array}$ & $\begin{array}{l}\text { High } \\
\text { dependence } \\
N(\%)\end{array}$ & $P^{\wedge}$ \\
\hline \multirow{3}{*}{$\begin{array}{l}\text { If you could choose the types of warning } \\
\text { labels on cigarette packs, which one do you } \\
\text { feel as more effective in helping to stop } \\
\text { smoking? }\end{array}$} & $\begin{array}{l}\text { Textual health } \\
\text { warning }\end{array}$ & $58(22)$ & 27 (11) & \multirow{3}{*}{0.003} & $22(14)$ & $62(18)$ & \multirow{3}{*}{0.319} \\
\hline & $\begin{array}{l}\text { Graphic health } \\
\text { warnings }\end{array}$ & $65(25)$ & $71(29)$ & & $41(26)$ & $94(28)$ & \\
\hline & $\begin{array}{l}\text { Both shocking } \\
\text { images with } \\
\text { text }\end{array}$ & 137 (53) & $149(60)$ & & $97(61)$ & $184(54)$ & \\
\hline
\end{tabular}

${ }^{\wedge} P$ value chi-square test; ${ }^{*} P$ value Fisher's exact test; ${ }^{\circ}$ the sample size in these cases is 32 ; bold: $P<0.05$.

TABLE 4: Multivariate logistic models to evaluate the effect of the pictorial shocking warnings.

\begin{tabular}{|c|c|c|c|c|}
\hline \multirow{3}{*}{ Independents variables } & \multicolumn{4}{|c|}{ Outcomes } \\
\hline & \multicolumn{2}{|c|}{$\begin{array}{l}\text { Agree with the fact that the shocking images } \\
\text { used on cigarette boxes have greater effect } \\
\text { than simple warning text currently used }\end{array}$} & \multicolumn{2}{|c|}{$\begin{array}{c}\text { Agree to change your favorite cigarettes } \\
\text { brand if a new look with shocking images on } \\
\text { smoking health damage was adopted by the } \\
\text { cigarette company }\end{array}$} \\
\hline & OR & CI 95\% & OR & CI 95\% \\
\hline$<45^{*}$ versus $\geq 45$ years & 0.59 & $0.36-0.97$ & 0.96 & $0.61-1.50$ \\
\hline Male $^{*}$ versus female & 0.64 & $0.39-1.07$ & 0.68 & $0.44-1.07$ \\
\hline $\begin{array}{l}\text { Low }{ }^{*} \text { versus high } \\
\text { motivation to quit }\end{array}$ & 1.30 & $0.78-2.15$ & 0.62 & $0.58-1.39$ \\
\hline $\begin{array}{l}\text { Low }{ }^{*} \text { versus high nicotine } \\
\text { dependence }\end{array}$ & 0.46 & $0.26-0.84$ & 1.5 & $0.94-2.38$ \\
\hline $\begin{array}{l}\text { Hosmer and Lemeshow's } P \\
\text { value test }\end{array}$ & & & \multicolumn{2}{|c|}{0.46} \\
\hline
\end{tabular}

${ }^{*}$ Reference group.

\section{Discussion}

According to the TNS Qualitative Eurobarometer study [15], there is a perception that people have become desensitized to health warnings labels and that they now "blend into" the packaging. Although most respondents claimed that they would not be motivated by health warnings alone to give up smoking, they felt they were important and should continue to feature on tobacco packaging.

Moreover, in agreement with several studies $[8,16-$ 20], the present findings showed that higher motivated to quit respondents who had been exposed to pictorial health warnings expressed the view that these were more impactful than text-only warnings ( $89 \%$ versus $78 \%, P=0.003)$. Consequently, it is possible to conclude that pictorial warnings should be more widely adopted instead of or in combination with text to help those who are already inclined to quit.

The typology of shocking warnings does not appear to be noticed in those who exhibit different levels of nicotine dependence. The Fagerström score does not highlight differences in the choice of the best type of warning to discourage tobacco consumption.

The pilot study [11] and the evidence suggest that pictorial warning labels, particularly those with graphic images, may be more persuasive among female populations [21, 22]; in the present study, $43 \%$ of the female respondents talked about changing the packet to avoid seeing the "shocking" image in comparison with the $32 \%$ of male ones.

According to the previous study, this research shows that the respondents aged $<45$ years were more sensitive to warnings (54\% present study; $65 \%$ previous study) [11]. The association with younger people is also evident in several studies too $[21,23,24]$.

About a third of respondents (36.2\%) said that the labels have increased curiosity about tobacco or desire to be better informed or to be helped to give up smoking, although in the lower dependence and higher motivated to quit groups the interest is around $40 \%$. Some studies suggest including telephone number/more information on clinics/pharmacies/a website address on the packets $[25,26]$ or including a reason why people should seek help, to improve the credibility of the message.

The study has a number of limitations. It is based on an opportunistic sample of smokers who voluntarily decided to take part in the study. In addition, the sample included different settings (general population but also respiratory disease patients and participants of smoking cessation programs). This may have introduced a selection bias in the results and, in fact, may have involved only special categories of smokers, for example, the most sensitive to the health problems group or hardcore group of smokers. To control some of these 
limits, the multivariate logistic model was applied using age, dependence to smoking, and motivation to quit.

It was also not counted the number of individuals who refused to fill in the questionnaire, and even the reasons for the rejection: maybe the most important limitation is not having evaluated if the questionnaire is usable for all types of smokers. This consideration could explain the high number of missing answers regarding the impression on the shocking images (between $18 \%$ and 39\%) in which it is not possible to give a correct interpretation: have the pictures disturbed and ill-disposed responders?

The impacts of the introduction of graphic health warnings on cigarette packs on the smoking-related behaviors, perceptions, and intentions of adolescents were not investigated.

The work looked cross-sectionally at the association between cognitive processing of the warning labels and smoking habits. The longitudinal analyses would have been conducted to determine if the graphic warning labels altered smoking intentions and behaviors.

In addition, the information collected in this study is selfreported and therefore can be affected by many factors. For example, the impact of a message or the its understanding can be influenced by social, demographic, environmental, and political characteristics and the responder's sensitivity may depend on the presence or absence of certain personal conditions.

This research suggests that, beyond communicating the health risks of smoking and protecting nonsmokers from the harmful effects of environmental tobacco smoke, the pictorial shocking warnings encourage to stop smoking or "to horrify" for good purposes the ones more motivated to quit, the young, and the female smokers. Despite these very encouraging results in some countries, the adoption of this way of communicating the health risks has not yet been adopted. Most likely, the introduction of warnings of this type is mainly slowed by economic interests of the tobacco industry [27].

Although tobacco companies have suggested that pictorial warnings "annoy" smokers, this research in accordance with the literature suggests that, overall, smokers welcome more health information on their packages, including information that presents the health consequences of smoking in a vivid, arousing manner [28].

In conclusion, the findings in accordance with the previous publication show that female and younger smokers appear to be more involved by shocking images. The jarring warnings appear to be supporting those who want to quit smoking. This is an Italian study that sought to strengthen the evidence already known in the international literature but which had not yet been explored in this country and provide additional reasons to the health advocates and policy bodies to pursue more efficient smoke-free and tobacco labeling policies.

\section{Conflict of Interests}

The authors have declared that no competing interests exist.

\section{Acknowledgments}

This work has been funded by internal Sapienza University funds. The funders had no role in study design, data collection, and analysis, decision to publish, or preparation of the paper.

\section{References}

[1] World Health Organization, WHO Report on the Global Tobacco Epidemic, 2011, World Health Organization, Geneva, Switzerland, 2011, http://www.who.int/tobacco/global_report/2011/en/.

[2] Office on Smoking and Health (US), The Health Consequences of Involuntary Exposure to Tobacco Smoke: A Report of the Surgeon General, Centers for Disease Control and Prevention (US), Atlanta, Ga, USA, 2006, Bookshelf ID: NBK44324, http://www.ncbi.nlm.nih.gov/books/NBK44324/.

[3] U.S. Department of Health and Human Services, The Health Consequences of Smoking: A Report of the Surgeon General, U.S. Department of Health and Human Services, Centers for Disease Control and Prevention, National Center for Chronic Disease Prevention and Health Promotion, Office on Smoking and Health, Atlanta, Ga, USA, 2004.

[4] OssFAD. Osservatorio Fumo, Alcol e Droga, Il fumo in italia, Indagine DOXA. Istituto Superiore di Sanità, 2012, http://www.iss.it/binary/fumo/cont/Indagine_DOXA2012.pdf.

[5] D. Hammond, "Health warning messages on tobacco products: a review," Tobacco Control, vol. 20, no. 5, pp. 327-337, 2011.

[6] J. F. Thrasher, V. Villalobos, A. Szklo et al., "Assessing the impact of cigarette package health warning labels: a cross-country comparison in Brazil, Uruguay and Mexico," Salud Publica de Mexico, vol. 52, supplement 2, pp. S206-S215, 2010.

[7] M. C. Willemsen, "The new EU cigarette health warnings benefit smokers who want to quit the habit: results from the Dutch Continuous Survey of Smoking Habits," European Journal of Public Health, vol. 15, no. 4, pp. 389-392, 2005.

[8] S. Azagba and M. F. Sharaf, "The effect of graphic cigarette warning labels on smoking behavior: evidence from the Canadian experience," Nicotine \& Tobacco Research, vol. 15, no. 3, pp. 708717, 2013.

[9] L. D. Cameron, J. K. Pepper, and N. T. Brewer, "Responses of young adults to graphic warning labels for cigarette packages," Tobacco Control, 2013.

[10] T. R. Partos, R. Borland, H. Yong, J. Thrasher, and D. Hammond, "Cigarette packet warning labels can prevent relapse: findings from the International Tobacco Control 4-Country policy evaluation cohort study," Tobacco Control, vol. 22, no. el, pp. e43-e50, 2013.

[11] A. Mannocci, D. Antici, A. Boccia, and G. la Torre, "Impact of cigarette packages warning labels in relation to tobaccosmoking dependence and motivation to quit," Epidemiologia o Prevenzione, vol. 36, no. 2, pp. 100-107, 2012.

[12] A. A. Sorensen, R. D. Wojahn, M. C. Manske, and R. P. Calfee, "Using the Strengthening the Reporting of Observational Studies in Epidemiology (STROBE) statement to assess reporting of observational trials in hand surgery," Journal of Hand Surgery. American Volume, vol. 38, no. 8, pp. 1584.e2-1589.e2, 2013, http://www.strobe-statement.org/?id=available-checklists.

[13] T. F. Heatherton, L. T. Kozlowski, R. C. Frecker, and K.-O. Fagerström, "The Fagerstrom test for nicotine dependence: a revision of the Fagerstrom tolerance questionnaire," British Journal of Addiction, vol. 86, no. 9, pp. 1119-1127, 1991. 
[14] G. la Torre, R. Saulle, N. Nicolotti, C. de Waure, M. R. Gualano, and S. Boccia, "From nicotine dependence to genetic determinants of smoking," in Smoking Prevention and Cessation, G. la Torre, Ed., pp. 1-21, Springer, London, UK, 2013.

[15] TNS Qual+, Directorate-General for Health and Consumers, Eurobarometer Qualitative Study. Tobacco Packaging Health Warning Labels-Aggregate Report, 2012, http://ec.europa.eu/ public_opinion/archives/quali/ql_5818_tobacco_en.pdf.

[16] J. Cantrell, D. M. Vallone, J. F. Thrasher et al., "Impact of tobacco-related health warning labels across socioeconomic, race and ethnic groups: results from a randomized web-based experiment," PLoS ONE, vol. 8, no. 1, Article ID e52206, 2013.

[17] L. M. Hassan, E. Shiu, J. F. Thrasher, G. T. Fong, and G. Hastings, "Exploring the effectiveness of cigarette warning labels: findings from the United States and United Kingdom arms of the International Tobacco Control (ITC) Four Country Survey," International Journal of Nonprofit and Voluntary Sector Marketing, vol. 13, pp. 263-274, 2008.

[18] R. Borland, H. Yong, N. Wilson et al., "How reactions to cigarette packet health warnings influence quitting: findings from the ITC Four-Country survey," Addiction, vol. 104, no. 4, pp. 669-675, 2009.

[19] R. Borland, N. Wilson, G. T. Fong et al., "Impact of graphic and text warnings on cigarette packs: findings from four countries over five years," Tobacco Control, vol. 18, no. 5, pp. 358-364, 2009.

[20] D. Hammond, G. T. Fong, A. McNeill, R. Borland, and K. M. Cummings, "Effectiveness of cigarette warning labels in informing smokers about the risks of smoking: findings from the International Tobacco Control (ITC) Four Country Survey," Tobacco Control, vol. 15, supplement 3, pp. iii19-iii25, 2006.

[21] D. Hammond, J. Thrasher, J. L. Reid, P. Driezen, C. Boudreau, and E. A. Santillán, "Perceived effectiveness of pictorial health warnings among Mexican youth and adults: a populationlevel intervention with potential to reduce tobacco-related inequities," Cancer Causes and Control, vol. 23, supplement 1, pp. 57-67, 2012.

[22] J. J. Koval, J. L. Aubut, L. L. Pederson, M. O’Hegarty, and S. S. H. Chan, "The potential effectiveness of warning labels on cigarette packages: the perceptions of young adult Canadians," Canadian Journal of Public Health, vol. 96, no. 5, pp. 353-356, 2005.

[23] J. F. Thrasher, M. J. Carpenter, J. O. Andrews et al., "Cigarette warning label policy alternatives and smoking-related health disparities," American Journal of Preventive Medicine, vol. 43, no. 6, pp. 590-600, 2012.

[24] J. F. Thrasher, E. Arillo-Santillán, V. Villalobos et al., "Can pictorial warning labels on cigarette packages address smokingrelated health disparities? Field experiments in Mexico to assess pictorial warning label content," Cancer Causes and Control, vol. 23, supplement 1, pp. 69-80, 2012.

[25] D. Hammond, J. L. Reid, P. Driezen, and C. Boudreau, "Pictorial health warnings on cigarette packs in the United States: an experimental evaluation of the proposed FDA warnings," Nicotine \& Tobacco Research, vol. 15, no. 1, pp. 93-102, 2013.

[26] C. L. Miller, D. J. Hill, P. G. Quester, and J. E. Hiller, "Impact on the Australian Quitline of new graphic cigarette pack warnings including the Quitline number," Tobacco Control, vol. 18, no. 3, pp. 235-237, 2009.

[27] P. A. Lopipero and L. A. Bero, "Tobacco interests or the public interest: 20 years of industry strategies to undermine airline smoking restrictions," Tobacco Control, vol. 15, no. 4, pp. 323$332,2006$.
[28] D. Hammond, "Health warnings on tobacco packages: summary of evidence and legal challenges," 2008, http://global .tobaccofreekids.org/files/pdfs/en/India-study-warningLabelsDHammond-Jan08.pdf. 


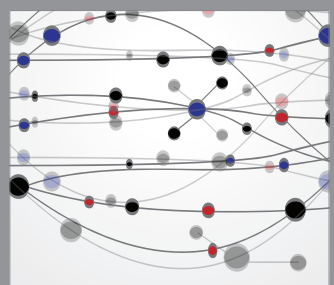

The Scientific World Journal
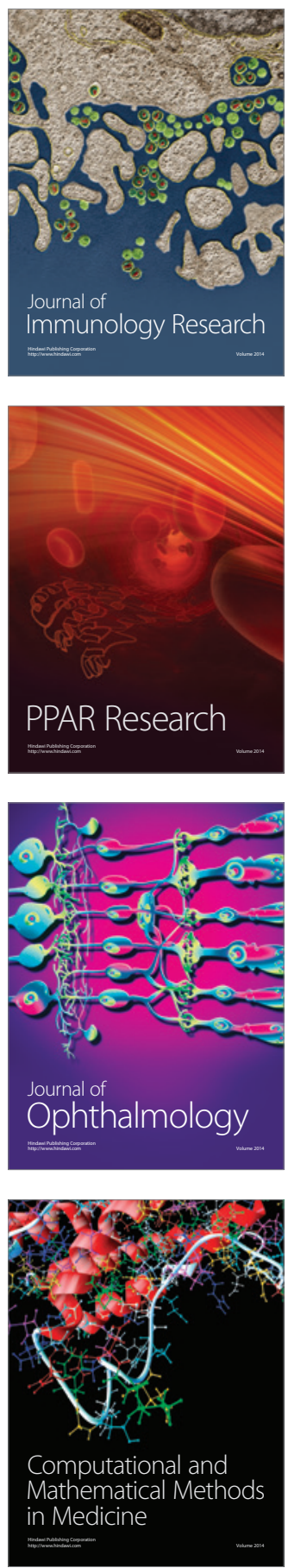

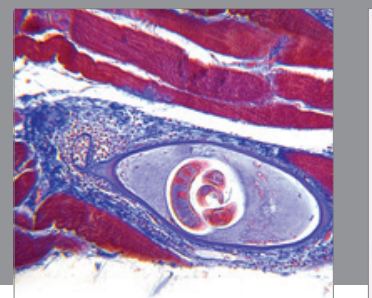

Gastroenterology

Research and Practice
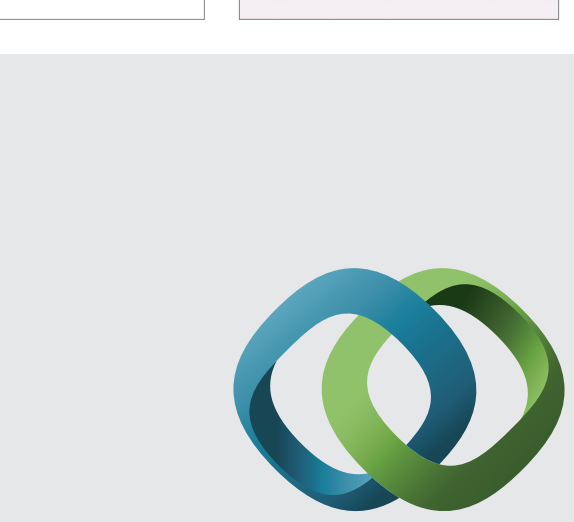

\section{Hindawi}

Submit your manuscripts at

http://www.hindawi.com
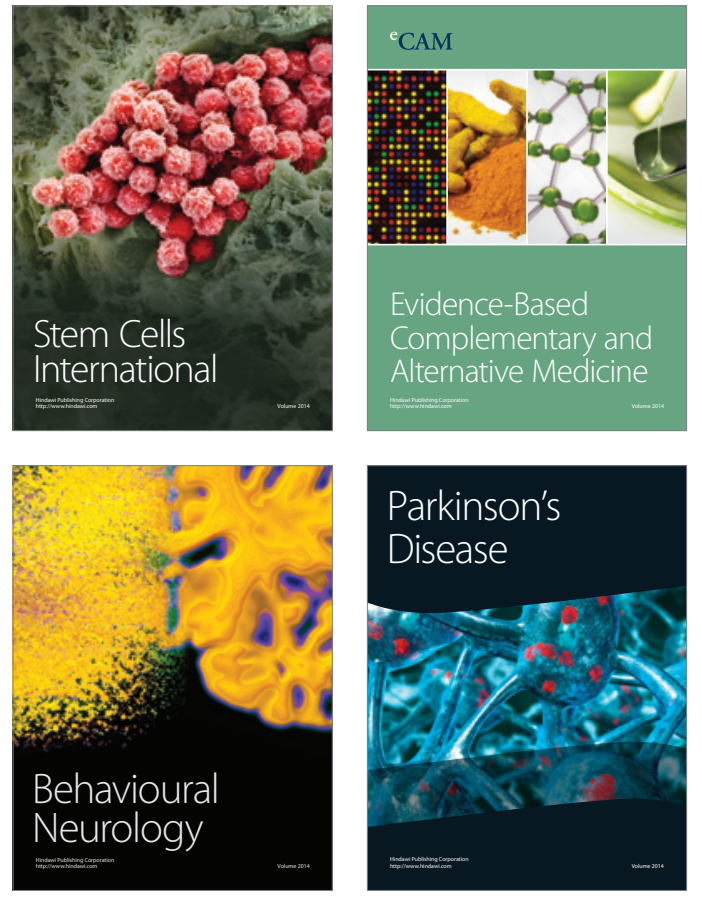
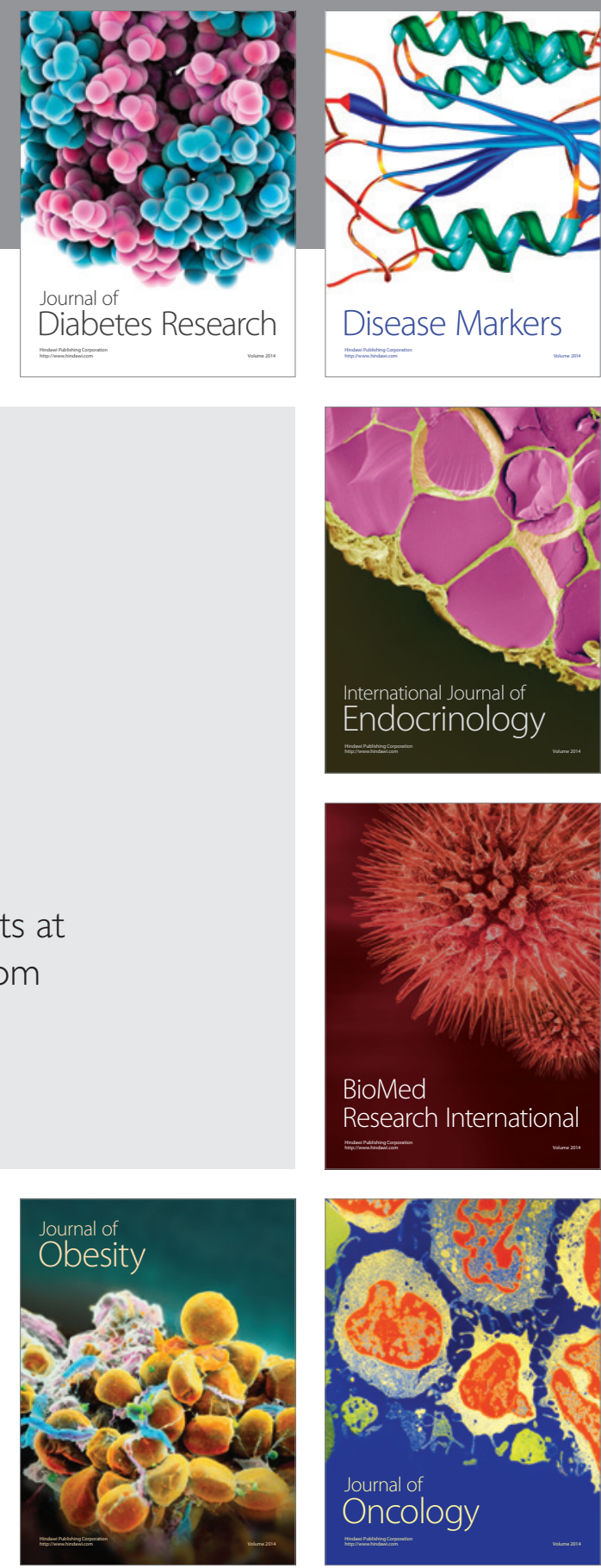

Disease Markers
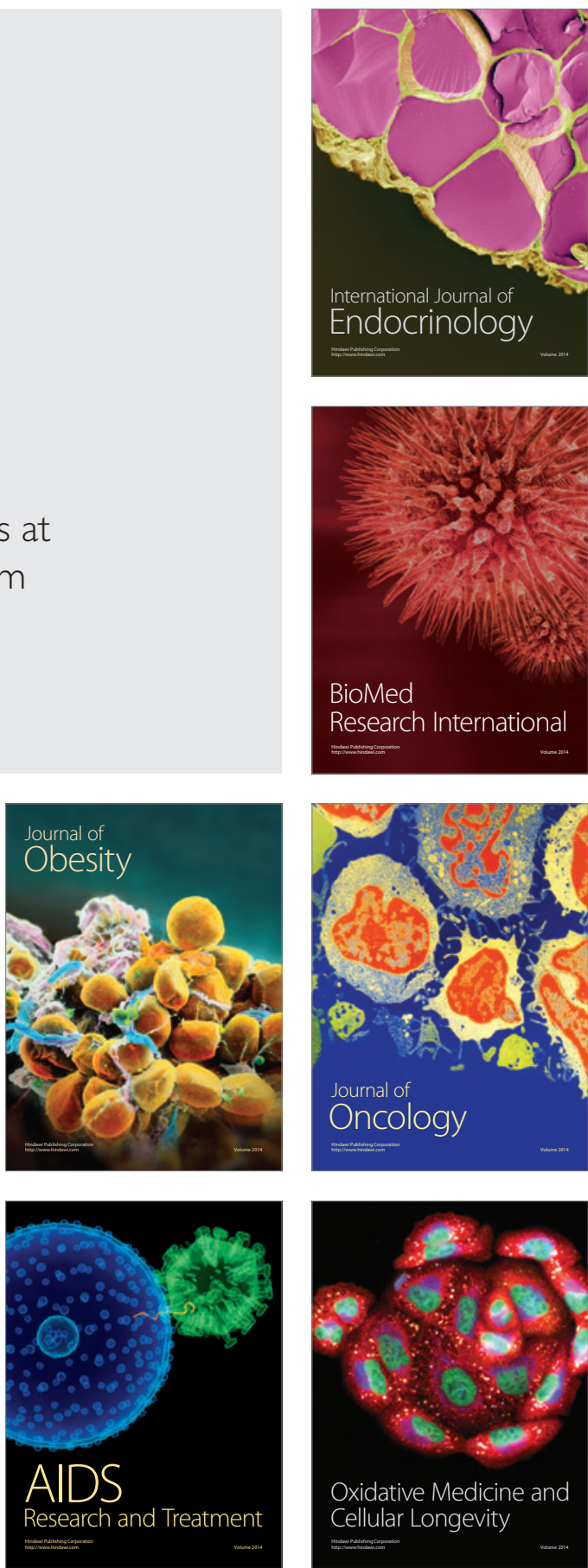